\title{
PENGARUH TERAPI SPORT MASSAGE PRA-EXERCISE TERHADAP PENINGKATAN AGILITY PADA PEMAIN SEPAKBOLA KLUB UTP SURAKARTA
}

\author{
Wisnu Mahardika', Eriek Satya Haprabu' ${ }^{2}$ \\ Prodi Pendidikan Kepelatihan Olahraga, Universitas Tunas Pembangunan Surakarta \\ ${ }^{1}$ wisnu.mahardika@gmail.com
}

\begin{abstract}
This current study aims at observing the influence of pre-exercise sport massage therapy towards the cultivation of agility to the football player of Universitas Tunas Pembangunan Surakarta. This study has been accomplished in 18 weeks. The population of the study is all of the football player of UTP Surakarta. The samples are 28 athletes. Based on the prerequisite test result, the normality test of the pretest group experiment is at 0,130, the post-test group experiment is at 0,161, the controlled pre-test is at 0,187, the controlled post-test is at 0,168. Based on the normality test, it can be concluded that all of the data are at 0,05 which means that the data distributes the normal frequency. Based on the homogeneity test, this study shows at 0,53 where the data depicts above 0,05, hence the data are homogeny. Based on the result of hypothesis test towards the pre-test and post-test experiment, it can be concluded that the significance level is at 0,328 >0,05, therefore the null hypothesis which reflects "there are no influence of pre-exercise massage therapy towards the increase of agility to the football player of Universitas Tunas Pembangunan Surakarta" is declined.
\end{abstract}

Keyword: Therapy, Sport Massage, Agility.

\section{PENDAHULUAN}

Melihat persepakbolaan yang semakin maju, mengharuskan pakar-pakar untuk meneliti agar berkembangnya permainan sehingga semakin majunya prestasi persebakbolaan baik nasional maupun klub-klub di Indonesia. Dengan informasi perkembangan model penelitian dan penerapan dalam sebuah penelitian akan menjadikan banyaknya pilihan dalam melakukan perkembangan demi kemajuan prestasi yang hendak di raih. Mengkaji dari beberapa permasalahan yang ada, mulai dari permasalahan inividu dan permasalahan tim yang harus segera diselesaikan peneliti melihat beberapa kali latihan persiapan kondisi kebugaran otot menjadi sorotan. Ini terlihat dalam rutinitas latihan pemain yang mengalami kelelahan otot yang merugikan karena dengan kelelahan otot akan mengurangi konsentrasi pemain dalam melakukan latihan tim.

Pengaruh latihan dengan intensitas tinggi sangat mempengaruhi penampilan permainan sepakbola klub UTP Surakarta. Dengan kompetisi yang cukup panjang dan persiapan yang 
cukup memaksa pemain untuk berada pada kondisi fisik yang selalu maksimal dalam satu musim pertandingan. Dengan pergerakan paling banyak pada ekstremitas bawah pemain harus memulihkan kondisi fisik dengan secepat mungkin sangat berpengaruh terhadap kemampuan agility pemain. Dengan melihat banyaknya komponen kondisi fisik yang harus dilatih pemain mulai dari koordinasi, power, kekuatan, keseimbangan dan kemampuan merubah arah, pelatih harus faham dalam penerapan semua aspek kondisi fisik untuk diterapkan dalam pelaksanaan program latihan yang maksimal.

Pelatih dan pengurus melakukan segala cara untuk menjaga dan memulihkan kondisi fisik terutama kemampuan agility pemain, baik dengan cara konsumsi makanan yang dimakan setiap pemain atau dengan suplemen untuk mengatasi kondisi kelelahan pemain. Dengan berbagai cara yang dilakukan peneliti melihat pemulihan kondisi fisik yang bisa dilakukan lebih cepat dengan menggunakan terapi sport massage. Peneliti melihat kinerja sport massage mengembalikan kerja otot dengan cara dipijat bisa lebih cepat pulihnya.

Pemberian sport massage sebelum melakukan latihan bisa mempersiapkan tubuh untuk melakukan latihan secara maksimal. Peneliti mengambil parameter agility untuk melihat seberapa besar peranan massage dalam mempersiapkan tubuh sebelum latihan. Agility merupakan salah satu kondisi fisik yang sangat penting dalam permainan sepakbola untuk menjaga konsistensi dalam permainan dalam satu kompetisi penuh.

Peneliti mengkaji bahwa agility membutuhkan tenaga dan kondisi fisik yang bagus. Ini mengakibatkan pemain menjadi rentan terhadap kecapekkan sehingga peneliti harus menemukan solusi untuk mengembalikan kondisi fisik dan peneliti menemukan solusi salah satunya adalah dengan sport massage.

Berdasarkan berbagai kajian yang dilakukan peneliti, mulai dari fisik pemain yang harus selalu bugar untuk memaksimalkan permainan sepakbola Klub UTP Surakarta untuk menjaga kemampuan agility maka Peneliti mengambil judul: Pengaruh terapi sport massage pra excercise terhadap peningkatan agility pada pemain sepakbola klub UTP Surakarta.

\section{METODE PENELITIAN}

Subjek Penelitian

Subyek dalam Penelitian ini adalah pemain sepakbola klub UTP Surakarta berjumlah 40 orang. Sedangkan sampel adalah sebagian atau wakil populasi yang diteliti (Sugiyono, 2010). Berpedoman pada konsep tersebut, maka sampel dalam penelitian ini adalah 
bagian dari populasi yaitu sebanyak 20 orang yang diambil secara acak (random)

\section{Teknik Pengumpulan Data}

Dalam Jenis penelitian yang digunakan ini adalah penelitian yang menggunakan eksperimen. Dalam penelitian eksperimen yaitu dilakukan kegiatan percobaan yang diawali dengan memberikan perlakuan kepada subjek yang diakhiri dengan suatu bentuk tes guna mengetahui pengaruh perlakuan yang telah diberikan dalam program latihan. Sedangkan rancangan yang digunakan yaitu Pretest-Posttest Design. Teknik pengumpulan data tes kelincahan menggunakan instrumen shutle run.

\section{Teknik Pengumpulan Data}

Pengambilan data the suttle run untuk mengukur kelincahan . Data yang sudah terkumpul dari hasil pengukuran, terlebih dahulu dilakukan uji normalitas data untuk mengetahui normal tidaknya distribusi data hasil pengukuran. Setelah data dikatakan normal, selanjutnya dilakukan uji homogenitas. Apabila data dikatakan normal dan homogen, untuk mengetahui adanya pengaruh kedua variabel bebas $\mathrm{X}_{1}$ (eksperimen) dan $\mathrm{X}_{2}$ ( kontrol) terhadap variabel terikat (Y) digunakan analisis uji-t dengan menggunakan aplikasi Statistical Package for the Social Science (SPPS) versi 3.1.

\section{HASIL PENELITIAN}

Penelitian ini dilakukan dengan metode eksperimen, variabel yang diukur adalah peningkatan agility pada pemain klub sepakbola UTP Surakarta. Pengukuran variabel dilakukan dua kali yaitu tes awal dan tes akhir. Tes awal dilakukan untuk membagi sampel kedalam kedua kelompok dan mengetahui tidak ada perbedaan pengaruh antara kelompok eksperimen dan kelompok kontrol sebelum diberikan perlakuan. Setelah itu kelompok eksperimen akan diberikan perlauan selama 6 minggu, dan disetiap minggu akan diberikan terapi sport massage pra exercise. Tahap terakhir setelah diberikan perlakuan pada kelompok eksperimen. Peneliti akan melakukan tes akhir yang mana bertujuan untuk mengetahui apakah terdapat perbedaan pengaruh antara kelompok eksperimen dan kelompok kontrol terhadap peningkatan agility pada pemain klub sepakbola UTP Surakarta.

Tabel 1 dapat dipahami sebagai berikut, bahwa : 1). Jumlah sampel pre test pada kelompok eksperimen adalah 14, dengan nilai minimum 15.07 dan nilai maksimum 12.78 , nilai mean 13.56 , nilai std. deviasi 0.68. 2). Jumlah sampel post test pada kelompok kontrol adalah 14, dengan nilai minimum 13.98 dan nilai maksimum 12,01, nilai mean 13.21 , nilai std. deviasi 0.42. 3). Jumlah sampel post test pada kelompok eksperimen adalah 14, dengan nilai minimum 14.10 
dan nilai maksimum 12.57, nilai mean 12.68, nilai std. deviasi 0.53. 4). Jumlah sampel post test pada kelompok kontrol adalah 14, dengan nilai minimum 13.41 dan nilai maksimum 12.46, nilai mean 12.81, nilai std. deviasi 0.30. Deskripsi data hasil tes dapat di lihat pada tabel 1 berikut.

Tabel 1. Data Kelompok Eksperimen dan Kontrol

\begin{tabular}{|c|c|c|c|c|c|c|}
\hline \multicolumn{2}{|c|}{ Sumber } & $\mathrm{N}$ & Min & Maks & $\mathrm{Me}$ & SD \\
\hline \multirow{9}{*}{$\begin{array}{c}\text { Pair } \\
1\end{array}$} & Pre Tes & 14 & 15.0 & 12.78 & 13. & 0.68 \\
\hline & Kelompo & & 7 & & 56 & \\
\hline & $\mathrm{k}$ & & & & & \\
\hline & Ekperim & & & & & \\
\hline & en & & & & & \\
\hline & Pre Tes & 14 & 13.9 & 12.01 & 13. & 0.42 \\
\hline & Kelompo & & 8 & & 21 & \\
\hline & $\mathrm{k}$ & & & & & \\
\hline & Kontrol & & & & & \\
\hline \multirow{9}{*}{$\begin{array}{c}\text { Pair } \\
2\end{array}$} & Post Tes & 14 & 14.1 & 12.57 & 12. & 0.53 \\
\hline & Kelompo & & 0 & & 68 & \\
\hline & $\mathrm{k}$ & & & & & \\
\hline & Eksperi & & & & & \\
\hline & men & & & & & \\
\hline & Post Tes & 14 & 13.4 & 12.46 & 12. & 0.30 \\
\hline & Kelompo & & 1 & & 81 & \\
\hline & $\mathrm{k}$ & & & & & \\
\hline & Kontrol & & & & & \\
\hline
\end{tabular}

Penelitian ini untuk melihat pengaruh terapi sport massage pra exercise terhadap peningkatan agility pemain klub sepakbola UTP Surakarta, maka dalam penelitian ini perlu dilakukan uji hipotesis, uji ini merupakan kegiatan statistic inferensial. Untuk melakukan uji ini ada dua hal yang harus diuji terlebih dahulu: 1). Apakah sampel yang telah diambil berasal dari populasi yang berdistribusi frekuensi normal?. 2). Apakah sampel yang telah diambil mempunyai varian yang sama?. Uji ini lebih dikenal dengan uji persyaratan analisis. (Singgih Santoso, 2005:209).

Hasil analisis yang terlihat pada tabel 1, kemudian dilanjutkan dengan iji persyaratan analisis hipotesis yang meliputi beberapa langkah sebagai berikut :

\section{Uji Normalitas Data}

Uji normalitas data dalam penelitian ini dengan statistic Shapiro Wilk. Adapun untuk menguji normalitas ini dengan ketentuan : bahwa jika nilai signifikansi atau nilai probabilitas < 0.05, maka data berdistribusi frekuensi tidak normal. Jika nilai signifikansi atau nilai probabilitas $>0.05$, maka data berdistribusi frekuensi normal. Dari perhitungan diperoleh hasilnya pada tabel 2 berikut.

Tabel 2. Hasil Uji Normalitas Data

\begin{tabular}{llccc}
\hline \multirow{2}{*}{ Kelas } & \multicolumn{3}{c}{ Shapiro Wilk } \\
\cline { 2 - 5 } & & Statistik & $\mathrm{df}$ & Sig. \\
\hline Peningkatan & Pre Tes & 0.904 & 14 & 0.130 \\
Agility & Kelompok & & & \\
$\begin{array}{l}\text { Pemain } \\
\text { Klub }\end{array}$ & Eksperimen & & & \\
\cline { 2 - 5 } $\begin{array}{l}\text { Sepakbola } \\
\text { UTP }\end{array}$ & Post Tes & 0.911 & 14 & 0.161 \\
Surakarta & Kelompok & & & \\
& Eksperimen & & & \\
\cline { 2 - 5 } & Pre Tes & 0.915 & 14 & 0.187 \\
& Kelompok & & & \\
& Kontrol & & & \\
\cline { 2 - 5 } & Pos Tes & 0.915 & 14 & 0.168 \\
& Kelompok & & & \\
& Kontrol & & & \\
\hline
\end{tabular}

Berdasarkan pada tabel 2, bahwa untuk pre tes pada kelompok eksperimen diperoleh nilai signifikansi sebesar $0.130>0.05$ adalah data berdistribusi frekuensi normal. Post tes pada kelompok eksperimen diperoleh nilai signifikan sebesar $0.161>0.05$ adalah data berdistribusi frekuensi 
normal. Pre tes pada kelompok kontrol diperoleh nilai signifikansi sebesar 0.187 $>0.05$ adalah data berdistribusi frekuensi normal. Post tes pada kelompok kontrol diperoleh nilai signifikansi sebesar 0.168 $>0.05$ adalah data berdistribusi frekuensi normal.

\section{Uji Homogenitas}

Uji homogenitas dalam penelitian ini dengan menggunakan Chi-Square dan dengan ketentuan : jika nilai signifikansi > 0.05 berarti data bersifat homogen, sedangkan jika nilai signifikansi $<0.05$, berarti data bersifat tidak homogen. Adapun dari perhitungan diperoleh hasil pada tabel 3 berikut.

Tabel 3. Hasil Uji Homogenitas Data

\begin{tabular}{lllllll|}
\hline \multirow{2}{*}{ Kelas } & $\begin{array}{l}\text { Levene } \\
\text { Statistic }\end{array}$ & df1 & df2 & Sig. \\
\hline $\begin{array}{llllll}\text { Peningkata } \\
\text { n Agility } \\
\begin{array}{l}\text { Pemain } \\
\text { Klub }\end{array}\end{array}$ & Based on Mean & 2.738 & 3 & 52 & .053 \\
\cline { 2 - 6 } $\begin{array}{l}\text { Sepakbola } \\
\text { UTP }\end{array}$ & Based on Median & 1.987 & 3 & 52 & .127 \\
\cline { 2 - 7 } Surakarta & and with adjusted & 1.987 & 3 & 40.4 & .131 \\
\cline { 2 - 7 } & Based on & 2.421 & 3 & 52 & .076 \\
\hline
\end{tabular}

Berdasarkan data pada tabel 3, bahwa semua data dari kelompok penelitian yang ada menunjukkan nilai signifikansi $>0.05$, dengan demikian dapat disimpulkan bahwa data tersebut bersifat homogen.

\section{Uji Hipotesis}

Uji hipotesis ini dimaksudkan untuk menguji perbedaan mean dari kelompok eksperimen dan kelompok kontrol dengan ketentuan : jika nilai signifikansi $>0,05$, maka $\mathrm{H}_{0}$ ditolak dan $\mathrm{H}_{1}$ diterima. Jika nilai signifikansi $<0,05$, maka $\mathrm{H}_{0}$ diterima dan $\mathrm{H}_{1}$ ditolak. Berdasarkan ketentuan diatas dan didasarkan pada perhitungan diperoleh hasil seperti tabel 4 berikut.

Tabel 4. Hasil Uji Homogenitas Data

\begin{tabular}{|c|c|c|c|c|c|c|}
\hline \multicolumn{7}{|c|}{ Paired Samples Test } \\
\hline & & \multirow{2}{*}{\multicolumn{2}{|c|}{$\begin{array}{c}\text { Paired } \\
\text { Differences }\end{array}$}} & \multirow{3}{*}{$t$} & \multirow{3}{*}{ df } & \multirow{3}{*}{$\begin{array}{c}\text { Sig. } \\
(2- \\
\text { taile } \\
\text { d) }\end{array}$} \\
\hline & & & & & & \\
\hline & & Mean & SD & & & \\
\hline Pair & Pre_Eksper. & .347 & .43957 & 2.961 & 13 & .011 \\
\hline 1 & Pre_Kontrol & & & & & \\
\hline Pair & Post_Eksper & .132 & .48621 & 1.017 & 13 & .328 \\
\hline 2 & PostKontrol & & & & & \\
\hline
\end{tabular}

\section{PEMBAHASAN}

Pijat kebugaran salah satu faktor tahap pemulihan jaringan otot dengan merileksasikan jaringan dengan teknik pemijatan atau treatmen. "Massage olahraga merupakan suatu tahap awal dalam metode fisioterapi sejak 3000 tahun yang lalu" [3]. Atau "Massage Olahraga yaitu masase yang khusus digunakan atau diberikan kepada orangorang yang sehat badannya terutama olahragawan" [4]. Sport massage merupakan beberapa solusi yang disajikan untuk memulihkan kondisi fisik bagi pemain yang mempunyai program latihan jangka panjang untuk meraih prestasi atau memulihkan pemain dengan ketatnya kompetisi pertandingan dalam satu musim liga sepakbola. Dengan pandangan terapi pijat yang memberikan efek 
penyembuhan dan pemulihan akan menjadikan pijat ini langkah lebih maju untuk persepakbolaan Indonesia karena mengubah pandangan pijat untuk orang yang sakit cidera atau penyembuhan sakit saja. Sport massage disamping memberikan solusi kebugaran disini juga memberikan padangan kepada masyarakat pentingnya menjaga kondisi tubuh setiap hari.

Permainan sepakbola yang sebenarnya permainan ini perpaduan antara teknik individu dan kerjasama tim antara 11 pemain kawan dan 11 lawan dengan memasukkan bola kegawan lawan, dan tim yang meciptakan gol paling banyak dinyatakan sebagai pemenang [2]. [11] "arti sebenarnya Permainan sepakbola dalam satu tim sepakbola adalah permainan bola besar yang dilakukan dalam 11 orang pemain terdiri dari 10 pemain dan 1 orang penjaga gawang yang bertugas mengamankan gawang supaya tidak kemasukan bola. Pemain ini diperbolehkan menyentuh bola menggunakan tangan dan seluruh bagian tubuhnya selama masih berada di area yang ditentukan".

Agility merupakan kemampuan kecepatan merubah arah. Kemampuan agility merupakan salah satu aspek kondisi fisik yang sangat penting untuk permainan sepakbola, Sedangkan [10], Kelincahan adalah merupakan kemampuan untuk merubah arah dan posisi sesuai dengan situasi yang dihadapi Kelincahan ialah kemampuan dari seseorang untuk merubah posisi dan arah secepat mungkin sesuai dengan situasi yang dihadapi dan dikehendaki [8]. Dengan melihat besarnya fungsi agility dalam olahraga, kondisi ini mempermudah pemain untuk memaksimalkan kemampuan individu sebagai penopang kemampuan tim dalam permainan sepakbola. Agility yang kelihatan dalam altifitas olahraga dalam keseharian disebut juga agility umum dan agility yang menonjolkan kemampuan olahraga tertentu merupakan agility yang disebut dengan agility khusus. Perbedaaan ini cenderung hanya pada sitim perototan saat melakukan gerakan yang dilakukan saja.

Kemampuan untuk merubah arah dalam sebuah olahraga baik olahraga individu atau tim adalah membutuhkan agility sebagai penopang atau pendukung kemampuan kondisi fisik. Dalam penerapan agility dalam sebuah olahraga akan menjadikan sebuah karakteristik agility kemampuan merubah arah, perubahan posisi tubuh seorang pemain dan perubahan arah dalam bagian-bagian tubuh dalam mendukung kemampuan kondisi fisik agility.

Faktor kondisi fisik agility ini merupakan faktor kondisi yang di susun oleh komponen koordinasi, kekuatan, kelentukan waktu reksi dan power untuk untuk memaksimalkan agility ini. Dengan agility ini dapat dilihat beberapa 
manfaat yang bisa kita petik yaitu memudahkan kita untuk mengkoordinasikan gerakan berganda dalam secara simultan dan memudahkan kita untuk menguasai teknik-teknik tinggi dalam sebuah cabang olahraga karena penguasaan teknik tingkat atas ini membutuhkan beberapa gerakan tingkat sulit untuk melakukannya.

Beberapa latihan agility untuk bisa melatih kelincahan dalam permainan sepakbola antara lain adalah lari dengan menggunakan rintangan diantaranya melompat, menerobos, memanjat, kemudian latihan squat jump dimulai dari loncat, jongkok lalu push up, kemudian lari dengan berkelok-kelok dengan menggunakan tiang sebagai media untuk berkeloknya.

Berdasarkan hasil analisis data tersebut diatas, hasil temuan penelitian antara lain: 1) Hasil perhitungan uji hipotesis pada data pre tes eksperimen dan uji hipotesis pada pre test control, maka dapat disimpulkan bahwa taraf signifikansi 0,11<0,05, dengan demikian hipotesis nihil yang berbunyi "Tidak ada pengaruh terapi massage pra exercise terhadap peningkatan agility pada pemain klub sepakbola UTP Surakarta" adalah diterima. Sehingga pada tes awal semua sampel memiliki sifat yang sama dan bisa diberikan perlakuan. Sedangkan hasil perhitungan diatas, pada uji hipotesis pada data post tes eksperimen dan uji hipotesis pada post tes eksperimen, maka dapat disimpulkan bahwa taraf signifikansi 0,328 > 0,05, dengan demikian hipotesis nihil yang berbunyi "Tidak ada pengaruh terapi massage pra exercise terhadap peningkatan agility pada pemain klub sepakbola UTP Surakarta" adalah ditolak. Sehingga pada tes akhir terdapat perbedaan antara kelompok eksperimen dan kelompok kontrol yaitu terdapat perbedaan antara atlet yang diberi perlakuan terapi massage pra exercise dan atlet yang tidak diberi perlakuan sehingga berdasarkan perbedaan mean terdapat perbedaan angka mean antara kelompok eksperimen dan kelompok kontrol. Kelompok eksperimen mendapatkan angka mean 12,68 dan kelompok kontrol mendapatkan angka 12,81 . Sehingga dapat disimpulkan atlet yang diberi perlakuan terapi massage pra excersise memperoleh hasil yang lebih baik dibandingkan kelompok kontrol.

\section{SIMPULAN}

Berdasar pada hasil analisis uji hipotesis dapat disimpulkan bahwa uji hipotesis pada data pre test eksperimen dan uji hipotesis pada pre test control, dapat disimpulkan bahwa taraf signifikansi 0,11<0,05, dengan demikian hipotesis nihil yang berbunyi "Tidak ada pengaruh terapi massage praexercise terhadap peningkatan agility pada pemain klub sepakbola UTP Surakarta.

Melihat hasil kesimpulan penelitian, maka saran yang dapat 
disampaikan adalah sebaiknya gerakan dilakukan dengan bola diam maupun bola yang bergerak sehingga perlu penelitian lebih lanjut dengan memperhatikan gerakan bola. Selain itu diharapkan dari hasil penelitian ini dapat dijadikan acuan referensi bagi para peneliti.

\section{DAFTAR PUSTAKA}

Ali Maksum. 2012. Metodologi Penelitian Dalam Olahraga. Unesa Univ. Press. Surabaya.

Andi Cipa Nugraha, 2016. Mahir Sepakbola. Bandung: Nuansa Cendikia.

Arif Setiawan 2015. Sport Massage. Yogyakarta: Magnum Pusaka Utama, Yogyakarta.

Basiran, Ling Ling Usli, Hendi Suhendi 2010. Masage Olahraga. Penerbit UPI Bandung.

Budi Susetyo, (2014). Statitistika Untuk Analisis Data Penelitian. Refika Aditama. Bandung.

Feri Kurniawan (2012). Buku Pintar Pengetahuan Olahraga. Jakarta: Laskar Aksara.
H. Nurhasan \& D. Hasanudin Cholil (2007). Tes dan Pengukuran Pendidikan Olahraga. Bandung: FPOK UPI

Syarif Hidayat.( 2014). Pelatihan Olahraga: Teori dan metodologi. Yogyakarta Graha Ilmu.

Sugiyono. (2008). Metode Penelitian Kuantitatif, Kualitatif dan RED. CV Alfabeta: Bandung.

Iman Imanudin. (2008). Ilmu Kepelatihan Olahraga. Bandung: Univ. Pendidikan Indonesia.

Teguh Sutanto. 2016. Buku Pintar Olahraga. Jogjakarta: Pustaka Baru Press. 